\title{
Images In Modern Uzbek Poetry
}

\author{
Shoxista Shodiyevna Nizomova \\ Bukhara State University pre-school and elementary \\ Teacher of the Department of pre-school education at the Faculty of Education
}

\begin{abstract}
Like other forms of art, fiction reflects the mental state and thoughts of the people in it. Life always consists of people's lives, work activities, struggles, emotions, experiences. The descriptive theme of literature is, first and foremost, man. There is no image of man, and there is no fiction where it is not intended. Accordingly, the concept that occupies a central place in the science of literature is also the concept of the image hero. The concept of image has a wide and narrow meaning. While the concept of emblem in the broadest sense represents a landscape of life in which the thoughts and feelings of the creator are embodied, in the narrowest sense it represents the image of a human being reflected in a work of art. This article looks into the imagery in modern Uzbek literature and poetry.
\end{abstract}

Keywords:

image, imagery, poetry, realistic, fiction, tragic, generalization.

Article Received: 18 October 2020, Revised: 3 November 2020, Accepted: 24 December 2020

\section{INTRODUCTION}

Image is less than the unity of content and form, theme and idea summarizes. In terms of a specific ideological-aesthetic task as an image people, events, nature, generalized and defined landscapes. Image is the basis of artistic thinking in literature and art tool is an important form of expression of ideological content. For this reason Speaking about the peculiarities of the image, $\mathrm{M}$. Gorpky said, "Image is an idea an economical way to grow" An image is an artistic picture of human life. Human while the artistic landscapes of his life are based on the following 4 Conditions in a Literary Work described:

- generalization; clarity, uniqueness;

- use of artistic fabric;

- Striving for emotion and emotion in the image.

Generalization. Any image is a generalization. Described in the play one thing and something like that and thousands on the ground of the incident the features and characteristics of the events will be summarized. So, in a play of art the people described are not just a few of the people in life, but most of them embodied few important traits and had an artistic integrity is a model.

Accuracy. By showing the writer the peculiarities of the artistic image together they define it, give the image vitality, vitality, naturalness. Everyone if the image is not portrayed as a multifaceted, unique trait, it will not be alive. So, every person in a real work of art is a language, and with that language, absolutely is a definite Person.

About artistic fabric A.Qahhor "From the reality of life to artistic fabric" The article said: "If a writer is copying from a marriage would not have been an easier task. Exactly copying from life is from the book it's like moving. The copy remains a copy. Originality from such things the wait is futile. Originality is the heartfelt realization of the truth of life the assimilation of sentences, the expression of desire. To the true impressions of the fiction writer's life his reasoning, his sincere feelings, his deep thoughts. Impressions are gained in a fluid, global, diffused way. The artistic image must really evoke emotion in the reader. If an image that reflects the ugliness of life arouses hatred in the reader, beauty the image he expresses evokes pleasure. Aesthetic ideal through the writer's artistic image describes: the ideal is expressed directly in a positive image and indirectly in a negative image. 
The writer approaches each image with passion and actively reacts to it must be. Impressions are gained in a fluid, global, diffused way. Here it is it is impossible to imagine an image without this feature. Types of image according to the creative method. According to the requirements of the creative method, the images are divided as follows: - Realistic: Yolchi, Kholishon, Shomurodov.

- romantic: Danko, Mehinbonu, Demon.

- fantastic: Ixtiandr.

- Legend: Gorogli, Alpomish.

- Symbolic: falcon, dawn, dove, sun, thunder.

- Mythological: Akhura Mazda, Akhriman, Zahhok.

- Satirical: Grace Elder.

- exaggeration: Gobsek, Alpomish.

- grotesque: Gargantyua, Gulliver, Munchausen.

- figurative-allegorical: parables, "The way to heaven", "Kutadgu bilig".

Realistic images are less than the characteristics of living people integrates. The heroes of Uzbek literature are realistic images.

\section{MATERIALS AND METHODS}

Romantic images are not exactly in life, but with a dreamy, uplifting spirit are irrigated images. For example, Farhod, SHirin, Mehinbonu in "Khamsa", Alexander the Great is one of them. The fantasy characters are incredibly exaggerated and miraculous are images. Fantastic images are more in the folklore as well occurs in the sci-fi genre of written literature. Legendary characters, on the other hand, are completely non-living, imaginary characters. they are described as having inexhaustible power. For example, Alpomish, Gorogly.

Symbolic images are social with objects, plants, animals, colors means generalization of events. For example, in A. Mukhtor's novel "Chinor" maple, a symbolic image of a dove in Uygun's poem "Pigeon of Peace" are examples. A group of symbolic images are also figurativeallegorical images is called.

In figurative-allegorical images birds, animals, insects are humanized. The heroes of the parables are such images. Mythological images are created in myths about nature and society images. In ancient Greek myths, Prometheus, Antey, Hercules, Dedal, Icarus, Athens, Kayumars, Ahriman, Mitra, etc. in the myths of Aphrodite, Erot, Arab and Central Asia mythological images.

As you know, literary genres are divided into prose, lyric and dramatic genres. The prose image is created in prose works by way of story, narration. Prose the heroes of the centuries will be prose characters. Lyrical imagery is an image of emotional experience, more so in lyrical poems occurs. In lyrical poems, images expressed through experiences are lyrical images is called. The protagonist of the lyrical work becomes the lyrical protagonist. The lyrical protagonist is often the poet will be few.

Dramatic characters are the heroes of the drama, and the character in the dramatic works is clear and is created abruptly. They are created by colliding with each other. Tragic. There are also heroes who have a destiny, they are called tragic, tragic characters. In large-volume works and the main assistant, depending on the position in the composition of the work images are available. Standing at the center of the events of the work, moving the plot, the main character is the person who carries little of the idea that the writer wants to express is called. Sometimes two or more images of the same significance occurs. They are called main or adjacent images (Saida and Kalandarov). Images that are less involved in a work of art are called auxiliary images. For example, Images of Mehri, Umid, Kozimbek, Oyniso, Zulfikarov. Image is not only a means of life, but also a means of influencing it. Writer as the image depicts certain aspects of life, its position, thing, and attitude to events is also manifested. For example: Mirzakarimboy's faces red as the crown of a rooster. It is the character's wealth, his little maturity, to appreciate the soul and take good care of the little one, as well as the author expresses a bitter, sarcastic attitude towards the protagonist, which is a negative feature of the image will give. In A. Qahhor's story "The old 
women wired the wire", the hero face is "like an apple cooked in soup", where it is no longer a mockery, but a humorous one we see the relationship.

It is usually compared to the face in the literature. But the red face of youth resembles an apple. In A. Qahhor's story, it is about the faces of an old woman apple metaphor was used. But it's not an ordinary apple, it's an apple cooked in soup. This is it with the writer: 1) Laughing using an apple simile against the old woman's face excites; 2) creates a real portrait: indicates his old age; 3) attitude indicates; not sarcastic, humorously mixed, impeccable; 4) style indicator: the writer's propensity for humor. Hence, the writer uses the image of events, people, and their reacts to their identities, judges them. So figurativeness is a feature of fiction. Image a means of thinking.

The image should affect not only the mind but also the emotions. That's it Thus, an image is a living, emotionally described event, thing and object, creature and person with a specific purpose. The image is always concrete. It is specific to many things and events. In addition to the general features, there are also unique features accumulates. Otherwise the image will not be vital. Only when it comes to individuality which is peculiar to a few things and events, which distinguishes it from others aspects are understood. Hence, the image is in the unique individuality of the common feature manifestation. A writer prototype can also be used to create an image. Of life there are few real types. They serve as a prototype for the writer he calls. In some cases, the writer is like a man who thinks in his imagination can meet a person in life. In this case, the artist's imagination to create an image, this person acts as a copy. Prototyping the significance is that it unites life, being, with tissue, the writer brings his fantasy closer to life. But the artistic image is alive The prototypes do not cover all the individual, minor features necessary for the image depicted from a certain ideological-aesthetic point of view takes only individual characteristics. So the image is something in life and not a copy of the events, but their artistic exploration and known is the result of being subjugated to an ideological intention. Life as an artist creates an image enlivens and enriches the facts with little imagination. Only the author the image created with the help of the texture will be vital and real. The writer's fantasy reveals the essence of events, the reality of life will be a means of realization. Created using the writer's imagination the image convinces the person that the reader is real, not fabricated accepts. Images created using the writer's imagination are without fantasy becomes more vivid and vital than the works described in detail. In fiction, an image is created through words. Like an artist the paint, like the composer's tones, is invisible to human life is able to give up to the sides.

Now, when it is spoken about the imagery in modern uzbek literature, it is essential to mention literary characters in Uzbek poetry and most outstanding modern poets.

Among the modern Uzbek poets and writers, one can distinguish Abdulla Aripov, Erkin Vakhidov, Sharaf Bashbekov, Khurshid Davron, and others. A famous Uzbek writer and playwright is Sharaf Bashbekov. Theaters of Uzbekistan are staging his plays "The Gate of Fate", "Gavroshi of the Old City", "The Iron Woman". The Iron Woman has been staged in many theaters of the former USSR. According to Sh. Bashbekov's script, the films "Faceless" (1992), "Golden Boy" (1993), "Iron Woman", "Maruf and Sharif" (1996), "Jester" were shot. The series "Ferris Wheel" brought great authority to the writer. The magic, the attractive power of the works of Sh. Bashbekov is in the peculiar characters and in the luscious language. Sh. Bashbekov for the drama "Iron Woman" was awarded the State Prize of the Republic of Uzbekistan (1990). One of the brightest symbols of the first decade of the era of Uzbekistan's independence was the Uzbek poet Muhammad Yusuf (1954-2001). According to his contemporaries, Muhammad Yusuf was one of the most gifted Uzbek poets of the late XX - early XXI century. 
In the mid-70s, talented youth came to our poetry: Miraziz Agzam, Usman Azimov, Khurshid Davron, Shavkat Rahmon, Muhammad Yusuf, etc. She formed her view of a person, social phenomena, history, moral and ethical problems, artistic creativity and his tasks.

From their predecessors, these poets inherited moral maximalism, while significantly strengthening, as if exposing this property. Usman Azim, Mukhammal Yusuf - in their poems they glorify boundless love for the Motherland, its greatness and independence. They directly address their contemporary, first of all, the younger generation. Their every poem is a passionate appeal to preserve the originality of their land, to show through images the continuity of generations.

The ideas of the time - striving for social justice and democratization could not but be consonant with the creativity of the new generation, in which the rejection of lies, injustice, hypocrisy and outright rebellion against meanness were the main motives. They act like a large, wellcoordinated, violent orchestra. Therefore, artistic research of moral issues from humanistic and democratic positions has now become even more intensified and deepened, further development has been obtained in poetry. One of the most talented poets of the last decade is Shavkat Rahmon. The poet is always very open and frank in his lines and at the same time modest, courageously restrained.

The poems of Muhammad Yusuf perfectly depict the Uzbek nature, it is always different, but very close and dear. Everything he saw and felt was embodied by the poet in poetry. And what poetry! There were no verbal adornments or poetic excesses in them. Such a sincere poetic voice was rare for Uzbek literature of the 20th century. The poems of Chulpan, Gafur Gulyam and Abdulla Aripov were distinguished by the same deep lyricism and at the same time directness and clarity. Conquers the freshness, spontaneity, heartfelt sincerity of the lyrics of Muhammad Yusuf, the cunning charm of his lines, the novelty and originality of genre sketches, their truly folk song beginning. The national flavor of his poetry, unique individual style made the poems of Muhammad Yusuf incredibly popular. The songs based on his poems live their own independent life, they are sung and loved. Muhammad Yusuf is characterized by extraordinary versatility in the perception of the world, responsiveness to every movement of life and an unrestrained flight of fantasy. Muhammad Yusuf was able to show life in its fullness and diversity. But life for him is love. Without her, he could not imagine himself either in life or in creativity. That is why all of his work is permeated with touching gentle and quivering notes.

And yet, the main theme of his poems was love for his native land. He always wrote about Uzbekistan: both at the beginning of his path, and in a later period of creativity. Although every poet writes about the Motherland, only he wrote so sincerely and uniquely. At the same time, the poems of Muhammad Yusuf dedicated to his native land are distinguished by a special mood, incredible plasticity and vivid imagery. Only the most devoted and faithful sons of the Fatherland could love the Motherland so much as Muhammad Yusuf loved it! This is how he writes about the Motherland in the poem "Uzbekistan". The days spent with you are a holiday for me, If I part with you, then I miss the topic. I bow before those who know you. I regret all those who do not know you.

\section{CONCLUSION}

Poems dedicated to the mother are closely related to the theme of the Motherland. They convey not only filial love for his mother, but also love for all mothers. Like any great poet, Muhammad Yusuf was engaged in translation activities. He did this selectively and approached his translations with great exactingness. Despite the fact that he himself studied the translations of the works of great poets, his translations are very original and the words of $\mathrm{V}$. Zhukovsky can be fully attributed to them: "A prose translator is a slave, a poetry translator is a rival." Every word, 
every event in his personal life was poetry for Muhammad Yusuf. He lived easily and brightly, he hovered like a bird above the ground. But the poet's life ended early. The creative flight was interrupted on takeoff. The only consolation is that a poet of such a scale, $h$ depth of feelings and thoughts as Muhammad Yusuf left us with his wonderful poems, which, no doubt, will have a huge beneficial effect on the development of Uzbek poetry. Poets, as if competing, turn to the same motives, revealing new facets of a theme common to all.

\section{REFERENCE:}

[1] I.Sultonov. Literary Theory T., $1980 \mathrm{y}$.

[2] Literary theory. 2 volumes. T., Fan, 1978,1979 .

[3] T.Boboev. Introduction to Literary Studies. T., 1981.

[4] N.SHukurov. Introduction to Literary Studies. T., 1980.

[5] E.Xudoyberdiev. Introduction to Literary Studies. T., 1985.

[6] Andre Bretonp. Manifesto of Surrealism. World literature. 2000, may. Pages 16-174.

[7] Eslen Hovarsdsholm. Modernism. World literature. January 2001.

[8] Dag Sulstad. Norwegian prose - European modernism. World literature. January 2001.

[9] A. Genis. The leading style of the twentieth century. World literature. 2001, september 